\title{
Dissertations
}

A

PSA is pleased to include here the names of individuals who have completed their doctoral dissertations at political science departments in the during the 2015. In order to provide the most accurate information possible, this list is based on data reported directly from departments. Dissertations are listed by fields of interest as labeled by APSA: American politics, comparative politics, international relations, methodology, political philosophy and theory, public administration, public law and courts, and public policy.

(See also, table 1.)

\section{AMERICAN POLITICS}

Keehyun Ahn: "American Militaries in US Congress: Another Military Transformation from the 103rd to the 112th Congress"; University of Kansas

Brian Alexander: "Partisan Ends: The Utilization of Conference Committees in a Polarized Congress"; George Mason University

Richard Anderson: "Interest-Driven Oversight and the Failure of Congressional Control of the Bureaucracy"; University of Michigan

Roger Austin: "Patterns of Failure: Rethinking Campaign Finance Reform-What Went Wrong?"; University of Florida

Andrea Barrick: "Gender, Policies, and Politics"; West Virginia Universty

Rachel Bitecofer: "Polarization in US Presidential Nomination Campaigns"; University of Georgia

Jacob Bobby: "Voting for Friends: A Study of Parasocial Interaction in the 2012 Presidential Campaign"; University of South Dakota

Chelsie Bright: "Racial and Political Inequalities in State Voter ID Laws"; University of Kansas

Dana Brown: "Parties Matter: The Impact of Pennsylvania's Parties on Women's Local Officeholding"; Rutgers University

Table 1

Dissertations by Field of Interest

FIELD

TOTAL

\begin{tabular}{lrc}
\hline American Politics & 69 & 26 \\
\hline Comparative Politics & 79 & 27 \\
\hline International Relations & 74 & 27 \\
\hline Methodology & 1 & 1 \\
\hline Political Philosophy and Theory & 31 & 11 \\
\hline Public Administration & 8 & 3 \\
\hline Public Law and Courts & 2 & 4 \\
\hline Public Policy & 12 &
\end{tabular}

Jennifer Cassidy: "See Jane Get Appointed: Gender, Representation, and Power in the American Federal Bureaucracy"; Brown University

Jeremy Castle: "Rock of Ages: Subcultural Religious Identity and Public Opinion Among Evangelical Millennials"; University of Notre Dame

Philip Chen: "Taking Campaigns Personally: The Big Five Aspects and Political Behavior"; University of Minnesota

John Cluverius: "PDF Grassroots Lobbying and the Economics of Political Information in the Digital Age"; University of North Carolina, Chapel Hill

David Cottrell: "Three Essays on the Political Consequences of Geographic Boundaries in US Political Institutions"; University of Michigan

Allison Dale-Riddle: "Geography, Partisanship, and the Politics of Group Threat"; University of Michigan

Anthony Daniels: "The Impact of Voter Suppression Laws on African American Participation in Florida and North Carolina from 1988 to 2012"; Wayne State University

Charles Doriean: "A Dynamic Theory of Party Discipline, Legislator Roll-Call Voting and Electoral Accountability in the US House"; University of Michigan
Benjamin Dworkin: "Collective Communication in Congress: Understanding and Assessing House Caucus Leadership Efforts to Win Press Coverage, 1981-2010"; Rutgers University

William Egar: "Obstruction, Opposition, and Partisan Conflict: Implications of Minority Party Electoral Incentives for the House of Representatives"; University of Wisconsin, Madison

Derek Epp: "Information Processing and the Instability of Political Outcomes"; University of North Carolina, Chapel Hill

Andrew Feher: "Essays on Legislative Behavior: Evidence from State Legislatures"; University of Michigan

Alicia Diana Forster: "American Political Behavior and the Role of Religious Context"; University of Florida

Hector Galano: "The Importance of Digital Skills in Understanding Online Political Behavior"; University of California, Santa Barbara

Sergio Garcia-Rios: "Perennial and Situational: A Study of Immigrant Identity Formation and Transformation"; University of Washington

Samuel Gedman: "The Dynamics of Compression on Presidential Nominations"; University of Mississippi

Julian Gottlieb: “The Protest News Framing Cycle: How News Attention and Framing Change over the Course of a Protest"; University of California, Santa Barbara

Brian Hanson: "Perceptions of Immigration as a Threat to the Good Life in Rural America"; University of Kansas

Chris Hare: "Constrained Citizens? Ideology and the American Voter"; University of Georgia

Portia Hemphill: "Rebel Without a Pause: Discovering the Relationship between Rap Music and the Political Attitudes 
and Participation of Black Youth"; University of Michigan

Jonathan Hensley: "Legal Argument, Issue Framing, and the Development of Campaign Finance Law on the Supreme Court"; University of Maryland, College Park

Heather Hodges: "Communicating Distance: What This Means for Environmental Public Opinion"; University of California, Santa Barbara

Jung-Min Hong: "Political Polarization and Independent Voters in American Politics"; University of Cincinnati

Nicholas Howard: "Members and Leaders in Senate Obstruction"; University of North Carolina, Chapel Hill

Kristyn Karl: "Missing the Message: The Measurement and Effects of Attention to Political Advertisements"; University of Michigan

Mi-son Kim: "Parties Without Brand Names: Causes and Consequences of Party Relabeling"; University of Iowa

Jared Knowles: "School Boards and Policy Shocks: Riding the Wave of State Policy Change at the Local Level"; University of Wisconsin, Madison

Martin Kobren: "Taxing Ourselves: Understanding School Tax Elections"; University of Maryland, College Park

Rebecca Kreitzer: "Policy Making at the Margins: The Modern Politics of Abortion"; University of Iowa

Amy Krings: "Building Bridges Where There is Nothing Left to Burn: The Campaign for Environmental Justice within a Southwest Detroit Border Community"; University of Michigan

Jonathon Kupka: "Toward a Concept of the Warrior Class: The Impact of SubCultures in Civil Military Relations"; University of Kansas

John Lappie: "Voter Behavior in Elections without Party Labels"; University of North Carolina, Chapel Hill

Lisa Lawrason: "Laughing Our Way to Stronger Democracy: Political Comedy's Potential to Equalize Political Interest and Political Knowledge in Community College Students"; Wayne State University

Ruoxi Li: "Multiple Representations in the US Congress"; University of Wisconsin, Madison

Eric Loepp: "Conflicting Cues: The Role of Race, Gender, and Policy Information in Primary Elections"; University of Pittsburgh
Marvin McNeese: "Win the Battlefield to Win the Battle: Essays on Interest Group Venue Shopping"; Rice University

Benjamin Meluksy: "Institutional Capacity in the United States"; University of Pittsburgh

Matthew Mendez: "In/Visible Constituents: The Representation of Undocumented Immigrants by State Legislators"; University of Southern California

Cassie Myers: "Hometown Influence: The Impact of Geography on Statewide Candidate Emergence and Success"; University of Missouri, St. Louis

Srinivas "Chinnu" Parinandi: "Devolution and Policy Experimentation under Federalism: Essays on Innovation and Emulation in the American States"; University of Michigan

Davin Phoenix: "Anger (Mis) Management? Racial Differences in the Emotional Foundations of Political Action"; University of Michigan

Eric Radezky: "Home Style in the 21st Century"; Rutgers Univerity

Molly Reynolds: "Exceptions to the Rule: Majoritarian Procedures and Majority Party Power in the United States Senate"; University of Michigan

Thomas Ringenberg: "Issue Voting in a Polarized Era: Ideology, Constituencies, and Policy Making in Congress"; University of Kansas

Zuzana Ringlerova: "Mass Public Support for the European Union: Diffuse or Specific in Its Character?"; Purdue University

Melinda Ritchie: "Backchannel Policymaking: Members of Congress Pursuing Policy Goals through the Bureaucracy"; University of Illinois, Urbana-Champaign

Katherine Robbins: "Governing Bodies: How the Organization of Social Groups Shapes Political Ambition"; University of Michigan

Ellen Rodrigues: "Sense of Community, Collective Efficacy, and Perceived Police Efficacy”; West Virginia University

Rike Rothenstein: "Out of Sync: Is There a Mismatch between the American Environmental Movement and Public Opinion?"; University of Cincinnati

Emily Schilling: "Reassessing Legislative Relationships: Capturing Interdependence in Legislative Position Taking and Votes"; University of Iowa
Kaitlin Sidorsky: "One Way or Another? Understanding Women's Paths to Appointed and Elected Office"; Brown University

James Sieja: "Do They Know Them When They See Them?: The ABA Standing Committee on the Federal Judiciary and Qualifications for the Federal Bench"; University of Wisconsin, Madison

Joel Sievert: "The Electoral Connection in the US Senate"; University of Georgia

Marissa Silber: "Leaving Implementation Behind: Understanding the Failures of the Bipartisan No Child Left Behind Act of 2002"; University of Florida

Michael Spivey: "Culture Warriors Go To Court: The Supreme Court and The Battle For The 'Soul' of America"; University of Maryland, College Park

Amy Stringer: "Embracing a Changing Electorate: The Political Incorporation of Latinos in the US"; University of Florida

Chanse Travis: "The Political Power of the Black Church"; University of Mississippi

Magic Wade: "Labor's Last Stand? The Great Recession and Public Sector Collective Bargaining Reform in the American States"; University of Minnesota

Gregory Wolf: "Parties in the American Electorate"; University of North Carolina, Chapel Hill

Joshua Yesnowitz: “Talking 'Bout My Generation: Student Politics, Institutional Developmnet and the Purposes of Higher Education in American Life"; Boston University

\section{COMPARATIVE POLITICS}

Kelly Clancy: "Grains of Doubt: A Comparison of the Politically Contested Visual Landscapes of Genetically Modified Organisms in the United States and Europe"; Rutgers University

Kira Jumet: "Why Do People Protest? Explaining Participation in the 2011 and 2013 Egyptian Uprisings"; Rutgers University

Gulbahor Saraeva: "Migration Policy Networks and Migrant-Sending States' 3R-Policy Prioritization"; Rutgers University

Andrea Aldrich: "National Parties and European Legislators"; University of Pittsburgh 
Abel Amado: "The Illegible State in Cape Verde: Language Policy and the Quality of Democracy”; Boston University

Santiago Anria: "Social Movements, Parties, and the Left In Latin America: The Bolivian MAS (Movement Toward Socialism) in Comparative Perspective"; University of North Carolina, Chapel Hill

Ignacio Arana Araya: "The Quest for Uncontested Power: How Presidents' Personality Traits Leads to Constitutional Change in the Western Hemisphere"; University of Pittsburgh

Bret Barrowman: “The Reformer's Dilemmas: The Politics of Public Sector Reform in Clientelistic Political Systems"; George Washington University

Kelly Bauer: "Policy Implementation and Contentious Action: Indigenous Territorial Demands in Post-Dictatorship Chile"; George Washington University

Halil Bilecen: "The Determinants of Voting Behavior in Turkey"; University of Houston

Adam Bilinski: "Paths to Success, Paths to Failure: Historical Trajectories to Democratic Stability"; University of Florida

Pelin Azer Binnet: "My Wife, My Choice: Reproductive Policymaking and Social Control in Turkey"; University of Minnesota

Emilie Blais: "The Uploading of National Policies in the European Union"; University of Pittsburgh

Lee Cojocaru: "Disputed Ethnic Identity and the Role of Public Education: The Case of Moldova"; Boston University

Juvenal Cortes: "Power to the Masses: the Rise of Direct Democracy in Latin America"; University of Southern California

John D’Attoma: “A Nation Divided: Assessing the Regional Effects of Institutions, Social Capital, and Civic Culture on Tax Morale in Italy"; University of Missouri, St. Louis

Joshua Dean: "Nationalism in the New European Union: The Influence of Nationalism on the Salience of, and Party Attitudes Toward EU Political, Economic, and Social Policies"; University of California, Santa Barbara

Ali Demirdas: "The Turkish Foreign Policy under the Justice and
Development Party: A Paradigm Shift"; University of South Carolina

Svetoslav Derderyan: "The Effects of the European Union on Corruption Control in Central and Eastern Europe Before and after Accession"; University of North Carolina, Chapel Hill

Barry Driscoll: “The Perverse Effects of Political Competition: Building Capacity in Ghana"; University of Wisconsin, Madison

Yannick Dufresne: "Absent Mandate? The Role of Positional Issues in Canadian Elections"; University of Toronto

Yoav Duman: "Bolstering the National Project: Competitive Nation Building and Immigration Policies in Catalonia, Israel, and Quebec"; University of Washington

Eli Feiman: "Why Parties of Power? Elite Strategies and Institutional Choice in Post-Soviet Eurasia"; University of Michigan

Sarah-Sophie Flemig: "Policy Change, Public Benefit, and the Charities Act 2006: A Case of the Emperor's New Clothes?"; University of Toronto

Cassandra Grafstrom: "It's About Time: Institutions, Election Timing, and the Economic Vote"; University of Michigan

Eric Hamilton: "International Politics and Domestic Institutional Change: The Rise of Executive War-Making Autonomy in the United States"; University of Southern California

Luke Hartman: "Identity, Discourse, and the Impact of EU Conditionality in the Western Balkans"; Boston University

Victor Hernandez Huerta: "Post-Election Disputes in Democracies: Challenging the Outcome of the Election as a Negotiation Strategy"; University of Notre Dame

Brian Humphreys: "Imagining Armies: Symbolic Dimensions of Military Power and Contested State Legitimacy in Iraq, 2003-2014"; Rutgers University

Trevor Johnston: "Authoritarian Bargaining and Economic Sabotage in the Arabian Gulf"; University of Michigan

Dong-Joon Jung: "Sources of Partisanship and Its Political Impact: Comparing the Western and Postcommunist Experiences"; University of Florida

Olga Kesarchuk: "Policy Choices of the Post-Soviet States Regarding Foreign Direct Investment in the Key Sectors of their Economies: the Experience of Kazakhstan, Russia, and Ukraine"; University of Toronto

Dongkyu Kim: "Foreign Direct Investment Under Globalization Dilemma”; University of Iowa

Kathleen Klaus: "Claiming Land: Institutions, Narratives, and Political Violence in Kenya"; University of Wisconsin, Madison

Nicholas Knowlton: “The Legacies of Democratic Experiments in Africa: Ghana's Democratic Trajectory in a Comparative Perspective"; University of Florida

Melanie Kolbe: "Why Liberal States Restrict Wanted Immigration: Citizenship Regimes and the Politics of Highly-Skilled Immigration Policy"; University of Georgia

Aleksander Ksiazkiewicz: "Genetic Links among Ideology, Cognitive Style, Big Five Personality, and Executive Functions"; Rice University

Diah Kusumaningrum: "Truth and Justice Versus Interdependence: Competing Modes of Reconciliation-The Case of Maluku, Indonesia”; Rutgers University

Mohamed Lamin: "Party Sysytems, Democratization, and Governance in Africa: Aligning Theory and Praxis Using Sierra Leone as a Case Study"; West Virginia University

Seonghui Lee: "What Makes Politics Interesting? How Political Contexts Shape Political Interest across the World"; Rice University

Ingrid Li: "Political Economy of Property Rights: Local Officials, Incentive Structure, and Private Enterprises in China"; University of South Carolina

Nick Lin: "The Electoral Cost of Coalition Governance and Elites' Behavior in Parliamentary Democracies"; Rice University

Jinjie Liu: "The Property Rights Coalitions and Redistributive Institutions: The Political Economy of Stock Market Regulatory Regime Change in China"; University of Wisconsin, Madison

Kevin Lucas: "Programmatic Political Competition in Latin America: Recognizing the Role Played by Political Parties in Determining the Nature of Party-Voter Linkages"; University of Minnesota

Laura Lucas: "The Voice of the People? Legislative Drafting Processes 
in Transitional and Developing

Democracies"; Boston University

Kyle Marquardt: "Language,

Identity, Separatism: Regional

Grievance and Collective Action in

Eurasia"; University of Wisconsin, Madison

Amanda Marziliano: "Tolerating Europe: Integration Without Identification"; Rutgers University

Darragh McNally: "Voting for Corruption: When Do Voters Support Corrupt Politicians?"; University of Maryland, College Park

Carlos Melendez: "Is There Life after Party System Collapse? Transitional Partisanships and Political Linkages under Post-Party System Collapse Scenarios-The Case of Peru in Comparative Perspective"; University of Notre Dame

Mathieu Mondou: "Policy-Making Dynamics and Emergent Technology: the Evolution of Biofuel Policy in the United States, Germany, and the European Union"; University of Toronto

Bradley Murg: "Impetus or Impediment: Market Power, Foreign Direct Investment, and Judicial Reform in Russia and Kazakhstan"; University of Washington

Peter Nasuti: “The Reformist Leviathan: Centralization of Power and AntiCorruption Initiatives in Georgia and Ukraine"; University of Wisconsin, Madison

Juan Negri Malbran: "Bureaucratic Appointments in Argentina"; University of Pittsburgh

Winifred Pankani Lindberg: "A Reversed Collective Action Dilemma and the Challenge of Enhancing Bureaucratic Capacity in Botswana and Ghana"; University of Florida

Nara Pavao: "Why We Don't Just Throw the Rascals Out: The Limits to Electoral Accountability for Corruption"; University of Notre Dame

Michael Pelz: "EU Enlargement and LGBT Rights: Explaining Variation in State Responses to LGBT Rights in Post-Communist Europe"; University of Toronto

John Polga-Hecimovich: "Bureaucratic Circumvention: Policy Delegation Strategies and Implementation Success in Low Capacity Bureaucracies, with Evidence from Latin America"; University of Pittsburgh
Nico Ravanilla: "Essays in Political Economy and Governance: Lessons from the Philippines"; University of Michigan

Botero Sandra: "Courts That Matter: Judges, Litigants, and the Politics of Rights"; University of Notre Dame

Emily Sellars: "Essays on Emigration and Politics"; University of Wisconsin, Madison

Matthew Spears: "For the Good of the Group: How Empathy and Self-Interest Simultaneously Condition Individual"; University of Illinois, UrbanaChampaign

Szymon Stojek: "Contextual Conditions X Ideological Predispositions Model of Immigration Related Political Attitudes and Behavior"; University of Georgia

Jeremy Streatfeild: "African State Formation: 3 Essays"; George Washington University

Dennis Sullivan: "Uncivil Wars: Does Kantian Adaptive Networks Theory Provide Significant Indication and Warning of Intra-State Conflict?"; Boston University

Zachary Taylor: "The Politics of Metropolitan Development: Ideas, Interests, and Institutions in the Making of Urban Governance in the United States and Canada, 180o-200o"; University of Toronto

Aberra Tesfay: "The Extent and Impacts of Decentralization Reforms in Ethiopia"; Boston University

Jason Thomas: "Examining the Effects of Incumbent Party Tenure on Election Outcomes"; University of Iowa

Huan-Kai Tseng: "Democratization and Central Bank Independence: A Comparative Study of Mexico and Taiwan"; George Washington University

Alina Vamanu: "Political Withdrawal among Immigrants and Refugees from Non-democratic Regimes: The Case of Romanians in the New York-New Jersey-Pennsylvania Metropolitan Area of the United States"; Rutgers University

Neil Vander Most: "Rethinking Integration: What We Can Learn from Social Psychology"; University of Illinis, Urbana-Champaign

Keith Weghorst: "Losing the Battle, Winning the War: Legislative Candidacy in Electoral Authoritarian Regimes"; University of Florida
Charles Malcom Williams: "Conflict, Corruption, and Consent: An Analysis of Popular Support in Afghanistan"; University of Kansas

Qingjie "Eddie” Zeng: "The Golden Age of Oligarchy? Institutional Constraints and Leadership Discretion in China's Cadre Management System"; University of Michigan

INTERNATIONAL RELATIONS

Caitlin Scuderi: "Heightened Otherness and Domestic Terrorism"; Rutgers University

Cristina Alvarez Mingote: "International Migration, Electoral Strategies and Home Country Elections"; University of Illinois, Urbana-Champaign

Jacob Aronson: "The Provision and Impact of External Support to Combatants in Civil Wars"; University of Maryland, College Park

Aaron Beitman: "Distributional Consequences and Executive Regime Types: The Politics of Foreign Direct Investment Incentives"; University of Minnesota

Svetla Ben-Itzhak: "When is Aid Effective in Reducing Terror?"; University of Kansas

Timm Betz: "Trading Interests: Domestic Institutions, International Negotiations, and the Politics of Trade"; University of Michigan

Luke Campbell: "The 'Importance of Winning': Affect, Just War, and the 'Familiarization' of Success"; University of Kansas

Gustavo Carvalho: "International Structure, Cooperation, and Sovereign Debt Crises: The Brazilian Debt Restructurings of 1898, 1931, 1983"; University of Toronto

Kyong Jun Choi: "Politics of Law Enforcement: Policing and Police Reform in New Democracies"; University of Washington

Brooke Coe: "Regional Identities and Dynamic Normative Orders in the Global South: A Comparative Study"; University of Minnesota

Sarah Cormack-Patton: "Citizens, Residents, and Guest Workers: A Transatlantic Analysis of Immigrant Rights and Political Cleavages"; University of Pittsburgh

Jacob Cramer: "Strategies of Resistance"; University of Arizona 
Emma Cutrufello: "Arming Agents or Assailants: A Principal-Agent Approach to Examining US Military Aid and Repression"; University of Maryland, College Park

Joshua Dix: "A Matter of Minds: Environments, Trust, and Civil War"; University of Georgia

Ralitsa Donkova: "Regimes of International Giving: The Politics of Public and Private Foreign Assistance in the United States, Britain, and Sweden"; University of Minnesota

Joelle Dumouchelle: "Regulating International Finance: The Genesis and Transformation of Central Banking Practices"; University of Toronto

Sirin Duygulu Elcim: “The Effects of Using Security Frames on Global Agenda Setting and Policy Making"; University of Massachusetts, Amherst

Cali Ellis: "Trust and Communication in Cross-Border Counterterrorism Networks"; University of Michigan

Charles Fagan: "Smothering the Baby in the Cradle? Reacting to the Rise of New Great Powers"; University of Notre Dame

Sarah Fisher: "The Affairs of Others: Decision Making and Third Party Interventions in Intrastate Conflict"; University of Georgia

Robert Galantucci: "Taking the Lead on Trade: Legislative Participation, Effectiveness and Strategy in Foreign Trade Policy"; University of North Carolina, Chapel Hill

Erika Garcia Gonzalez: "The Onset of Genocide/Politicide: Considering External Variables"; University of Cincinnati

David Gordon: "From Global Cities to Global Governors: Power, Politics and the Convergence of Urban Climate Governance"; University of Toronto

Stephan Hamberg: "Electoral Violence in New Democracies: Institutionalizing Peaceful Elections"; University of Washington

Eric Hamilton: "International Politics and Domestic Institutional Change: The Rise of Executive War-Making Autonomy in the United States"; University of Southern California

Lisel Hintz: "Fighting for Us, Inside and Out: National Identity Contestation and Foreign Policy in Turkey"; George Washington University
Chien-Wu Hsueh: "Embedded Liberalism and the Trade-Conflict Relationship in World Politics"; University of South Carolina

Jacqueline Ignatov: "Seeds of Contestation: Genetically Modified Crops and the Politics of Agricultural Modernization in Ghana"; University of Maryland, College Park

Theresa Jedd: "Accountability and Legitimacy in Transboundary Network Forest Governance: A Case Study of the Roundtable on the Crown of the Continent"; Colorado State University

Florian Justwan: "The Effects of Generalized Social Trust on the Conflict Management Behavior of Democracies"; University of Georgia

Inwook Kim: "Crude Security: Oil, Armament, and Alliance"; George Washington University

Peter Knaack: "Global Financial Regulatory Reform in the G2O and the Financial Stability Board"; University of Southern California

Athena Kolbe: "Reintegrating Members of Armed Groups into Society: An Evaluation of Three Approaches"; University of Michigan

Hyo won Lee: "Legalization of the GATT/WTO and Distribution of Its Dispute Settlement Benefits between Developed and Developing Countries"; University of Washington

Jamie Levin: "Rethinking Disarmament: The Role of Weapons in the Resolution of Internal Armed Conflicts"; University of Toronto

Kuen-Da Dalton Lin: "Buying Your Way to Periphery Influence: Patronage Politics at Great Powers' Peripheries"; University of Wisconsin, Madison

Andrew Lucius: "Why Cities Fail: Local Political Institutions and the Fates of Metropolitan Economies"; University of Minnesota

Joseph MacKay: "Experimental Wars: Learning and Complexity in Counterinsurgency"; University of Toronto

Anthony Marcum: "To Dictate the Peace: Power, Strategy, and Success in Military"; University of Maryland, College Park

Jadon Marianetti: “The Chinese Communist Party's Changing Faces: The Role of the International Community and Its Domestic Population in Shaping China's Policy"; University of Florida
Naoko Matsumura: "The Effects of Foreign Audiences in International Dispute Settlements"; Rice University

Diane Maye: "Switching Sides: Political Power, Alignments, and Alliances in Post-Saddam Iraq"; George Mason University

Michael McDonald: "The Social Impact of Intellectual Property Rights: Public Health, Education, and Income Inequality"; University of Maryland, College Park

Medlir Mema: "Shifting Alliances: States, TANs, and the Making of the Rome Statute"; George Washington University

Elizabeth Menninga: "Multiparty Mediation: Identifying Characteristics of the Mediation Dream Team"; University of North Carolina, Chapel Hill

Kayce Mobley: "Revenge, Proportionality, and International Relations"; University of Georgia

Steve Mucci: "Managing Political and Investment Risk in the International Oil and Gas Industry"; University of Missouri, St. Louis

Bappaditya Mukherjee: "Domestic Political Consequences of Interstate Wars"; University of Maryland, College Park

Yousef Munayyer: "The Smoking Gun: Toward Understanding the Decision Calculus behind Repression Outcomes"; University of Maryland, College Park

Boraden Nhem: "The Cambodian Civil War and the Vietnam War: The Communist vs. the Western Way of Counterinsurgency"; University of Delaware

Victor Olivieri: "New Model Europeans: How Regional, National, and European Identities Interact to Forge What It Means to Be European"; University of Florida

Zhengqi Pan: "Global Value Chains and Production Networks: State-Business Relations and Complexity in Economic Crises"; University of North Carolina, Chapel Hill

Soul Park: "Deciding on Defeat: The Strategic Approach to War Termination"; University of Notre Dame

Joonui Park: "Trade Wars and Currency Conflict: China, Japan, and South Korea's Responses to US 
Protectionism, 1971-2013"; Boston University

Amy Pond: "The Political Economy of Market Liberalization"; University of Michigan

Molla Reda: "The Wartime Basis of Postwar Political Development: Civil War Termination, Resource Mobilization, and State-Building"; University of Minnesota

Bryce Reeder: "The Push and Pull of War: The Political Geography of Rebel Behavior During Wartime"; University of Illinois, Urbana-Champaign

Brett Remkus Britt: "LGBT Rights in Contemporary Global Politics: Norms, Identity, and the Politics of Rights"; University of Delaware

Ali Sanaei: "Domestic Politics of Asymmetric Wars"; University of Michigan

Fiorella Jazmin Sierra: "Partners at Home and Abroad: The Globalization of StateLed Development"; Brown University

Kieun Sung: "A Study on Rebel Group Dynamics and Third Party Intervention"; University of Iowa

Steven Torrente: "Toward a Political Ethics of Torture"; University of Kansas

Ashly Townsen: "The Rebellious Mind: Explaining Which People Become Rebels"; University of Illinois, Urbana-Champaign

Joannie Tremblay-Boire: "International Grantmaking by American Foundations"; University of Washington

Murat Ulgul: "Militarization of Ethnic Conflict in Turkey, Israel and Pakistan"; University of Delaware

Hamish van der Ven: "Eco-Labeling and the Conditions for Rigorous RuleSetting Transnational Governance"; University of Toronto

Tristan Volpe: "Proliferation Persuasion: Coercive Bargaining with Nuclear Technology"; George Washington University

Madeleine Wells: "Stay in Your Lane! How Regimes Balance Political Opposition in the Arabian Gulf"; George Washington University

Matthew Wells: "Commitment and Counterinsurgency: Essays on Domestic Politics and Patterns of Violence in Wars of Occupation"; University of Michigan

Jonathon Whooley: "Imagining Iran: Orientalism and Security Development in American Foreign Policy"; University of Florida

Seanon Wong: "When Passions Run High: Emotions and the Communication of Intentions in Face-to-Face Diplomacy"; University of Southern California

Serhan Yalciner: "Rebel Leaders and Conflict Processes: An Individual Level Analysis"; University of Mississippi

In Tae Yoo: "Power and International Economic Integration: Comparing Institutions of Regional Economic Integration"; University of South Carolina

Patty Zakaria: "Understanding the Behavior of States as Nuclear Status Changes"; Wayne State University

\section{METHODOLOGY}

Kwokwai Wan: "Economic Voting Dynamics: Electoral Implications of Monetary Policy Shifts And Partisan Policy"; University of Houston

\section{POLITICAL PHILOSOPHY AND}

\section{THEORY}

William "Zev" Berger: "Affective Trust and the Role of Social Norms in Constructing Faith in Others"; University of Michigan

Lorna Bracewell: "Beyond Barnard: Feminism, Liberalism, and the Sex Wars"; University of Florida

Claire Brault: "Time to Leave Uchronia: Queer Eco-Temporalities for a Livable World"; University of Massachusetts, Amherst

Joseph Brutto: "The Many Faces of Aristotle: Neo-Aristotelianism and Contemporary Political Thought"; University of Notre Dame

Mauro Caraccioli: "Naturalizing Empire: Missionary Science, Natural History, and the New World Narrative of Civilization"; University of Florida

Andrea Cassatella: "Jacques Derrida and the Theological-Political Complex"; University of Toronto

Amanda Cook: "Breastfeeding, Feminism, and Political Theory"; University of North Carolina, Chapel Hill

Ross Edwards: "Crisis of the Republic: Memory, History, and the Hermeneutics of Citizenship"; University of Minnesota
Maegen Gandy: "The Politics of Insurgency"; University of Maryland, College Park

Caleb Goltz: "Becoming Responsible: Conceptual Change in the Emergence of Tort Law"; University of Minnesota

Samantha Hill: "The Promise of Mourning"; University of Massachusetts, Amherst

Merom Kalie: "Ethics and Politics in the Thought of Martin Buber and Albert Camus"; University of Toronto

Robert L'Arrivee: “The Roots of Islamic Political Philosophy: A Comparative Study of Alfarabi's Virtuous City and Political Regime"; University of Notre Dame

Matthew Lepori: "Place, Nature, and Political Economy: The Submerged Politics of Alternative AgriFood Movements"; University of Massachusetts, Amherst

William Nichols: "Defining the Republic"; Wayne State University

Shellee Obrien: "A Madisonian Framework for Civic Involvement"; University of Houston

Elva Orozco-Mendoza: "Undying Protests: On Collective Action and Practices of Resistance against Feminicide in Ciudad Juárez"; University of Massachusetts, Amherst

Cameron Sabadoz: "Searching for the Social: Corporate Social Responsibility and Economic Regulation beyond the State"; University of Toronto

Manu Samnotra: "Between Shame and Courage: Reflections on Hannah Arendt's Political Thought"; University of Florida

Abraham Singer: "The Form of the Firm: A Critical and Normative Political Theory of the Corporation"; University of Toronto

Brannon Smith: "Philosopher Kings, Then and Now: The Political Philosophy of IQ"; University of Maryland, College Park

Brian Smith: "Friends, Natives, and Republicans: Three Essays on John Locke and the Natural Law"; Boston University

Laurel Sprague: "Inclusive Representation in Global Decision-Making Processes: Challenges of Democracy, Sovereignty, and Liberatory Politics for Marginalized Groups"; Wayne State University 
Mauricio Suchowlansky: "Machiavelli's Republicanisms: Society, Discord and the Politics of Equilibrium in the Florentine Histories"; University of Toronto

Kirstine Taylor: "Racial Violence and the Politics of Innocence: From the Postwar South to Post-Racial America"; University of Washington

Serdar Tekin: "The Founding Act of the People: Democratic Theory and the Problem of Founding"; University of Toronto

Matthew Van Hook: "Alexander Hamilton: A Theory of Statesmanship"; University of Notre Dame

Leslie Wee: "The Nature-History Debate in Rousseau's Thought"; University of Toronto

Ilya Winham: "After Totalitarianism: Hannah Arendt, Isaiah Berlin, and the Realization and Defeat of the Western Tradition"; University of Minnesota

Jeremy Wolf: "The Economy Effect"; University of Massachusetts, Amherst

Amanda Zeddy: "Rethinking Rural Spaces: Lived Experiences of Politics and Political Information in Appalachia"; University of California, Santa Barbara

\section{PUBLIC ADMINISTRATION}

Vincent Adejumu: "The Influence of Interest Groups Who Represent the For-Profit Higher Education Industry on American Political and Bureaucratic Institutions"; University of Florida

Jason Barrett: "Examining the Effect of Government Structure and Size on the Performance of Mississippi Community Water Systems"; Mississippi State University

Joseph Denton: “Testing Local Municipality Hiring Procedures and
Local Forms of Government: Are Search Engines and Social Media Sites Used to Collect Supplemental Information"; Mississippi State University

Nicole Fifer: "A Study of Performance Based Budgeting Reforms in the National Park Service and Their Effects on Agency Management and Operations"; Wayne State University

Jonathan Fisk: "Fracking and Goldilocks Federalism: The Too Loud, Too Quiet, and Just Right Politics of States and Cities"; Colorado State University

Jonathan Rauh: "The Effects of Political Control and Institutional Structure on State Ethics Commissions"; University of South Carolina

Asif Shahan: "From Autonomy to Relevance: The Evolution of the Government Accountability Office"; George Mason University

Rachel Yon: “Lip Service’ for Girls: Policy Implementation and the Juvenile Justice System"; University of Florida

\section{PUBLIC LAW AND COURTS}

Alyx Mark: "The Politics of Civil Legal Assistance in the United States: Three Essays on the Development, Maintenance, and Delivery of Legal Services"; George Washington University

Rebecca Reid: “The Domestic Adoption of International Human Rights Law: The Roles of Regional and National High Courts in Latin America"; University of South Carolina

\section{PUBLIC POLICY}

Amelia Andrews: "Enlightening the Experts: The Effect of Frames and Values on Expert Attitudes"; Purdue University
Marquita Bowers-Brown: "The St. Louis Desegregation Transfer Program: Do African American Students Perform Better in an Integrated Suburban Setting?"; University of Missouri, St. Louis

Derek Glasgow: "Unequal State Air Pollution: Adopting and Adapting to State Clean Air Policy"; Univesity of Kansas

John Holbein: "Making Good Citizens: Policy Approaches to Increasing Civic Participation"; Duke University

David Houle: "Carbon Pricing in Canadian Provinces: from Early Experiments to Adoption (1995-2014)"; University of Toronto

Jennifer Hove: "A Struggle for Hearts and Minds: Statebuilding and Origins of Political Legitimacy in Post-2001 Afghanistan"; University of Toronto

Alexandra Joosse: "Power in Collaborative Networks"; University of Arizona

Alexander Jorgensen: "Public Safety Intervention: Analyzing the Effects of Altering Traffic Safety Policies in the States"; University of Kansas

Meelis Kitsing: "Tacit Web: Entrepreneurial Discovery, Institutional Complexity, and Internet Diffusion"; University of Massachusetts, Amherst

Michel Martinez: "Photography: Power, Politics, Social Justice"; University of Southern California

Doris Schartmueller: "Life Imprisonment in Scandinavia: The Ultimate Punishment in the Penal Environments of Denmark, Finland, and Sweden"; Northern Arizona University

Galen Stocking: "The Dynamics of Attention: Agenda Setting in the Modern Media Environment"; University of California, Santa Barbara 